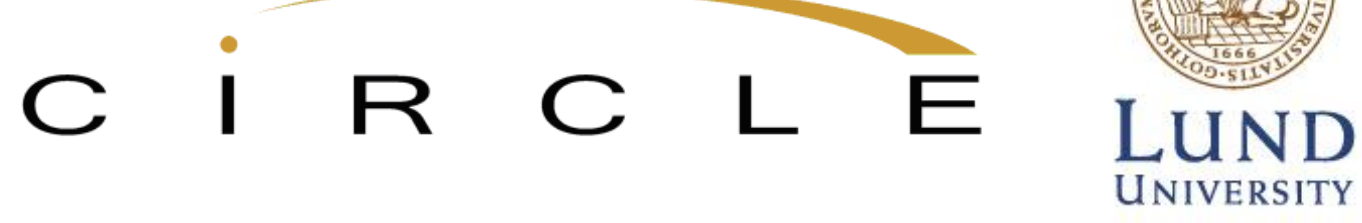

Paper no. 2012/06

\title{
Competences as drivers and enablers of globalization of innovation: Swedish ICT industry and emerging economies
}

\author{
Cristina Chaminade \\ (e-mail: Cristina.Chaminade@ circle.lu.se) \\ CIRCLE, Lund University
}

Claudia de Fuentes

(e-mail: claudia.defuentes@smu.ca) Saint Mary's University, Canada

This is a preprint version of a paper submitted to a journal for publication

Centre for Innovation, Research and Competence in the Learning Economy (CIRCLE)

Lund University

P.O. Box 117, Sölvegatan 16, S-221 00 Lund, SWEDEN

http://www.circle.lu.se/publications

ISSN 1654-3149 
WP 2012/06

Competences as drivers and enablers of globalization of innovation: Swedish ICT industry and emerging economies

Cristina Chaminade and Caludia de Fuentes

\section{ABSTRACT}

The objective of this paper is to discuss the relationship between competences and the global innovation networks in the Swedish ICT industry using both survey data and information from a case company- TELEQUIP. The paper portrays the interplay between the availability of competences in the home country as well as in the host country, with the specific strategy of the firm for engaging in global innovation networks.

Keywords: competence, globalization, global innovation networks, Sweden.

JEL codes: F23, $\mathrm{O} 32$

Disclaimer: All the opinions expressed in this paper are the responsibility of the individual author or authors and do not necessarily represent the views of other CIRCLE researchers. 
Competences as drivers and enablers of globalization of innovation: Swedish ICT industry and emerging economies

Cristina Chaminade

CIRCLE, Lund University, Sweden

Claudia de Fuentes

Saint Mary's University, Canada

This version: March 2012

\section{Introduction}

The objective of this paper is to discuss the relationship between competences and the global innovation networks in the Swedish ICT industry using both survey data and information from a case company- TELEQUIP ${ }^{1}$. The paper portrays the interplay between the availability of competences in the home country as well as in the host country, with the specific strategy of the firm for engaging in global innovation networks.

The paper starts by discussing the interplay between competences and globalization of innovation, distinguishing between region and firm-level competences. Global Innovation Networks (GINs) are defined in this paper as "a globally organized network of interconnected and integrated functions and operations by firms and nonfirm organizations engaged in the development or diffusion of innovations" (Chaminade 2009). Firms can globalize their innovation activities by engaging in the global exploitation of innovations (exports), global sourcing of technology, global research collaboration and offshoring of innovation (Archibugi and Michie 1995;

1 The real name of the company is not disclosed, due to confidentiality agreements. 
Audretsch and Feldman 1996). This paper is concerned with the last two forms of GINs.

Competences may influence global innovation networks in at least two ways: as drivers of globalizations and as enablers of globalization. Scholars in international business and innovation studies (Arora, Gambardella et al. 2001; Arora and Gambardella 2004; Arora and Gambardella 2005) argue that firms pursuing an asset seeking strategy (Howells 1990) may be attracted to a certain region to tap into the specific competences available there (Narula and Zanfei 2004). Therefore competences may play a role as a driver for the establishment of global innovation networks, notably, for global research collaboration and offshoring for innovation, as the evidence of knowledge hubs like Bangalore shows (Arora, Arunachalam et al. 2001; Saxenian 2001; Parthasarathy and Aoyama 2006; Chaminade and Vang 2008). On the other hand, firm-level competences may also be enablers for the establishment of innovation networks (Nooteboom 2000; Nooteboom 2004; Nooteboom, Van Haverbeke et al. 2007) and international networks. Competences define the absorptive capacity of a firm (Cohen and Levinthal 1990) which in turn, influences the ability of an organization to benefit from engaging in collaboration with other organizations. It also affects the ability of the firm to operate in international environments. Thus competences are also an enabler for the engagement in GINs.

Through regression analysis using survey data and in-depth interviews with TELEQUIP in different world locations (Sweden, South Africa and China), the paper explores the interplay between globalization of innovation and competence building, from two perspectives:

a) Which competences globally dispersed companies need and how are they managed? - competences as an enabler

b) To what extent the access to competences may be the driver for the location of R\&D labs abroad? - competences as a driver

The paper is structured as follows. First, it introduces the conceptual framework exploring the relationship between firm and regional competences and globalization. Next section present the method used for this paper. Section 4 is centred on the 
empirical evidence of relationship between globalization of innovation and competences in the ICT industry in Sweden in general and in multinational firm in particular. Last section of the paper concludes with some reflections on the role of competences in GINs, based on the Swedish experience.

\section{Conceptual framework}

\subsection{Global innovation networks}

It is widely accepted that innovation is the result of the interaction and exchange of knowledge between different individuals and organizations (Freeman 1987; Lundvall 1988; Lundvall 1992). Scholars in the innovation literature have contributed to our understanding of networks of innovators (De Bresson and Amesse 1991; Freeman 1991; Powell and Grodal 2004) particularly with regards to the structure of the network (Burt 1992; Dickens 2007), the governance of the networks (Humphrey and Schmitz 2002; Nooteboom 2003; Coe, Dicken et al. 2004; Gereffi 2005) and its impact on knowledge distribution among the actors of the network (Giuliani and Bell 2005; Giuliani 2007) but substantially less on its geographical spread.

On the other hand, the geography of innovation networks has been the focus of economic geographers for almost two decades (Cooke 1992; Asheim and Isaksen 1997; Mothe and Paquet 1998). Traditionally, economic geographers have argued that due to its tacit nature, knowledge is sticky and tends to be embedded in certain regions or territories. Local or regional networks of innovators are then considered to be crucial for innovation and competitiveness and most of the contributions were rather endogenous - i.e. looking at regional networks and ignoring networks at other geographical levels. The seminal work by Bathelt, Maskell and Malmberg on global pipelines- open a new venue of research on the interplay between local/global. Bathelt et al. (2003) argued that the most competitive clusters were those that showed a high degree of local interactions but also strong linkages with international sources of knowledge. Almost all the scholarly work that has followed on local/global knowledge interactions (Moodysson 2008; Moodysson, Coenen et al. 2008; Martin and Moodysson 2011) has been mainly treating the international level as a black box ignoring whether those international linkages were with countries in close proximity 
or whether they were globally spread and constituted truly global innovation networks.

As indicated in the introduction, global innovation networks are defined in this paper as a "globally organized network of interconnected and integrated functions and operations by firms and non-firm organizations engaged in the development or diffusion of innovations" (Chaminade 2009). This definition highlights the main characteristics of a GIN: its global dispersion, its focus on innovation (and not production) and the combination of both internal and external networks. Following Archibugi and Michie (1995), it is possible to distinguish different modes of global innovation networks: the global exploitation of innovations, global sourcing of technology, global research collaboration and global generation of innovation. Firms may globally exploit their innovations simply by selling their products abroad; they may innovate by acquiring technology from abroad or by engaging in research collaboration with firm and non-firm organizations located in a different country and, finally, they may also develop innovation through offshoring R\&D labs abroad (global generation of innovation). This paper is concerned with the last two forms of GINs. The interplay between these two forms of GINs and competences will be discussed next.

\subsection{Competences as an enabler for globalizing innovation activities ${ }^{2}$}

The resource based view of the firm (Teece 1980; Wernefelt 1984) has long argued that the strategy that firms may pursue is contingent to the competences and the capabilities that the firms have (Wernefelt 1984; Grant 1991; Barney 1996; Eisenhardt and Martin 2000; Barney, Wright et al. 2001). In a similar vein, the international business literature claim that the success of the internationalization process is also dependent on some firm's competences like the previous experience of the firm in international markets as well as the capability of the firm to organize internally the connections between the headquarters and the subsidiaries(Dunning and Narula 1995; Dunning, Narula et al. 1997). Finally, innovation scholars have long maintained that the capability to innovate and engage in interactive learning with

\footnotetext{
2 This section is based on Plechero and Chaminade, 2010.
} 
other organizations and individuals in highly contingent to the technological competences that the firm has (Cohen and Levinthal 1990; Lall 1992; Bell and Pavitt 1995\{COHEN, 1990 \#1948).

The different modes of globalization of innovation may be affected by a variety of competences and capabilities like the qualification of the human resources, the previous international experience (Sousa, Martínez- López et al. 2008) or the educational background, international experience or commitment of the managers of the company (Sousa et al, 2008). In line with previous studies (Plechero and Chaminade, 2010) in this paper we will focus on those more related to the globalization of innovation: the qualification of the human resources, the firms level of technological competences and the firms organizational competences.

Qualified human capital is considered to be central for building the absorptive capacity of the firm (Cohen and Levinthal, 1990) and thus is determinant of the ability of the firm to locate, acquire and use information and knowledge from other organizations, such as other firms, users or knowledge providers (i.e. research institutions. Human capital is considered to be crucial for engaging in interactive learning which, in turn, is conducive to innovation. We might therefore expect that the qualification of the human capital is an important enabler for global research collaboration and for global generation of innovation.

$R \& D$ or, more explicitly, intramural investments in $R \& D$ are expected to serve not only the generation of innovation but also to facilitate the acquisition of knowledge from external sources (Cohen and Levinthal, 1989). The more the firm knows, the more it is able to learn and therefore, the more that it will benefit from the interaction with other sources of knowledge. R\&D may therefore to be considered directly related to the ability of the firm to benefit from global research collaboration.

The development of new forms of organization and coordination to manage disperse knowledge is typical from asset seeking strategies (Dunning and Lundan, 2009). Both the coordination of $R \& D$ and innovation activities globally as well as the engagement in research networks requires the introduction of organizational innovations at the 
firm level (Dunning and Narula 1995; Knight and Cavusgil 2004; Sabiola and Zanfei 2009\{ Sabiola, 2009 \#5864). The coordination of R\&D activities between R\&D subsidiaries and the headquarters is organizationally very complex, as it involves the integration of both internal and external networks and requires advanced managerial and organizational competences. Firms with higher organizational competences are expected to be related to strategies of global research collaboration and global generation.

We may therefore expect that firms internal competences -such as the educational level, the R\&D investment or the organizational innovations- may act as enablers for the engagement in GINs, particularly for the global research collaboration as well as the global generation of innovations.

\subsection{Competences as a driver for the globalization of innovation activities: offshoring and global research collaboration}

One of the traditional arguments in international business literature explaining the internationalization of production and innovation activities has been the exploitation of existing advantages. The OLI framework developed by (Dunning 1993; Dunning 2001) in the early nineties argued that multinational companies expanded their activities abroad to exploit their competitive advantage in terms of ownership, location and internalization. Dunning (1993) refers to four different strategies for internationalization: market seeking, resource seeking, efficiency seeking and asset seeking, being the first three more related to asset exploiting strategies (Knight and Cavusgil 2004).

The distinction between asset exploiting and asset seeking strategies is particularly relevant for the globalization of innovation activities in general, and for the global generation and global research collaboration in particular and has important implications for the role of competences as a driver for the engagement in global innovation networks. While it is true that some companies may locate R\&D labs abroad to adapt existing products to the specific market needs (asset exploiting), there is growing evidence of the increasing importance of asset seeking strategies in the localization of R\&D abroad (Howells 1990; Zander 1999; Zanfei 2000). Firms are 
attracted to certain regions or engage in research networks to tap into specific competences and knowledge available in that particular region or network.

Traditionally technological competences have been concentrated in a handful of developed countries and regions (Li, Poppo et al. 2010). But the technology clubs of the world are slowly changing (Castellacci and Archibugi 2008). In 2006 the UNCTAD published a report on Research and Development (R\&D) Foreign Direct Investment which pointed, almost for the first time, to the changing role of developing countries in the global flows of innovation-related investments (Unctad 2006). It showed how R\&D investments to and from developing countries had increased dramatically in a few years. Innovation had become truly global, involving organizations and regions outside the high-income countries.

One of the most often cited arguments explaining this global shift is the accumulation of competences in certain regions around the world, like Bangalore in India (Arora, Arunachalam et al. 2001; Saxenian 2001; Arora 2006; Partharasarathy and Aoyama 2006) or Beijing in China (Altenburg, Schmitz et al. 2008). Thus some regions in developing countries have become knowledge hubs in global value chains (Castellacci and Archibugi 2008), particularly in ICT industries (Chaminade and Vang 2008).

We may therefore expect that the knowledge or competences available in a certain host region is an important driver at least for the offshoring of innovation activities (global generation of innovation) .

\section{Method}

This paper combines the analysis of survey based data with a case study to illustrate with more detail the complex relationship between competences and global innovation networks from a managerial perspective.

\subsection{Survey}

The survey captures information about the different dimensions of the globalization of innovation for each firm, such as global technological collaboration (R\&D strategy, 
sources of technology, establishment of networks for sourcing/developing technologies or innovations), and global generation of technology (offshoring). The survey also captures information about structural characteristics of the firm, such as size, industry, specific activities, and the main functions performed by the firm. Finally, it also captures information on competences at firm level such as qualification of the human resources, investments in $\mathrm{R} \& \mathrm{D}$, organizational management techniques, etc.

The dataset used for the survey contains all the Swedish companies that according to Statistic Sweden operate in ICT in the following NACE 2 codes: (26.30 Manufacture of communication equipment; 62.01 Computer programming activities; 62.02 Computer consultancy activities; 62.03 Computer facilities management activities; 62.09 Other information technology and computer service activities). The size of companies in the database is small, medium- size and large organizations. We excluded in the survey the firms with less than 5 employees.

The survey was web-based are directed to the entire ICT population. Firms were contacted by email and asked to conduct the survey online. The final number of companies contacted by mail were 1662. The final number of responses (complete questionnaires) was 194. The response rate was therefore $11,7 \%$. The distribution of responses by firm size and subindustry is representative of that of the total population of the industry (using statistics from statistics Sweden). Of the total sample, we have selected the companies that have engaged in global research collaboration or global generation of innovation.

We estimate the relationship between competences and globalization of innovation using a regression model. We use two models to capture the two forms of global innovation networks considered in this paper, one for global research collaboration and one for global generation of innovation.

\section{Dependent variables}

Global research collaboration: In the survey the firms were asked who did they actively collaborate with for the development of their most important innovation in the last 3 years. The firms were also asked to indicate the geographical location of the 
partner (the region, the country and globally). The options available included clients, suppliers, competitors, consultancy companies and universities. We created a dummy variable that takes the value 1 when the firm has answered positively to collaboration with any source at global level, and 0 otherwise

Global generation of innovation: In the survey the firms were asked if they had offshored R\&D activities. The firm could only answer yes/no. Therefore, the global generation of innovation is a variable that takes the value 1 when the firm has offshored R\&D and 0 otherwise.

\section{Independent variables}

Human capital: We use two variables to capture the qualification of the human capital in the firm. In the survey we asked the firms to indicate the estimated proportion of the employees by level of education. The three options were technical education/training, university degree and postgraduate degree. We created two dummy variables "employees with university degree" and "employees with postgraduate degree" that takes value 1 if the firm responded affirmatively to each of the categories respectively.

$R \& D$ activities: We use three variables to capture the $R \& D$ activities of the firm. The first one is a dummy "R\&D activities" that takes the value 1 if the firm had answered Yes to the question "do you have any significant R\&D activity?". The second one is a numerical variable with the number of full time equivalents employed in $R \& D$. The third one captures if the firm had engaged in intramural $R \& D$ and is derived from the question "Did your company engage in any of the following innovation activities in 2008”- being the options intramural R\&D, extramural R\&D, design, training and acquisition of machinery and equipment.

Other organizational competences: The variable "service innovation" captures if the firm has introduced any service innovation in the last three years; the variable "Support innovation" takes the value 1 if the firm has answered positively to the question "has the firm introduced new of significantly improved supporting activities for your processes (e.g. purchasing, accounting, maintenance systems, etc) in the past three years (2006-2008)"? or to the question "has the firm introduced new or 
significantly improved logistics, distribution or delivery methods for your inputs, goods and services in the past three years?" independently on the degree of novelty of that innovation. The variable "Advanced production systems" is a numerical variable that captures the number of systems of production organization that the firm employs. The available options were quality control systems, just in time production, continuous improvement, quality circles, internal manual and others. Finally we also asked the firms to estimate the percentage due to products "manufactured by your unit according to design specifications provided by external buyers" (Original Equipment Manufacturing-OEM), "developed and designed by your unit according to performance requirements of buyers" (Original Design Manufacturing-ODM) and "developed and designed by your unit and sold under your own brand" (Original Brand Manufacturing- $O B M)$.

Regional competences: If the firm had answered yes to the question on whether it had offshore production or innovation, they were asked to indicate "what were the important regional factors in the decision to offshore production and innovation into a host region". The different options available captured market, costs and knowledge drivers separately for production and innovation. For the variable "Host region competences" we use only the ones regarding the offshoring of innovation activities. The variable takes the value 1 if the firm has marked the "availability of specialized knowledge in the host region", the "availability of qualified human capital at a lower cost than in your own country" or "access to knowledge infrastructure and services in the host region (R\&D infrastructure, technical support services, etc)" as important factors explaining the decision to offshore innovation. To capture the level of competences in the home region, we created the variable "Home region Tier" ${ }^{\text {, }}$ We have categorized regions where the firms are located in Tier 1, Tier 2 and Tier 3, based on the industry dynamism. Tier 1 regions are the most dynamic and firms located there can have higher level of technological capabilities, also networks among agents and knowledge flows are more mature than in Tier 2 or Tier 3 . Tier 2 regions present a medium level of interaction among the members of the network, and firms located in Tier 2 have a medium level of technological capabilities. Tier 3 regions are the least dynamic and interactions among the members of the network are weak.

\footnotetext{
${ }^{3}$ For a more detailed description of how this variable is constructed, please refer to Chaminade and Plechero (2011)
} 
Region Tier is an original categorical variable that represents the dynamics and importance of the ICT industry in different regions in Sweden. We assigned the Tier level based on information about employment, economic dynamism, and industrial activities for each sector in each particular country. In Sweden, Tier 1 is the region around Stockholm (including Kista), Tier 2 is Göteborg and Skåne and Tier 3 is the rest.

Additionally we include a variable capturing the type of firm (standalone, subsidiary and headquarter) and another one for the size of the firm. Below is the description of the variables:

Table 1. Descriptive statistics

\begin{tabular}{|c|c|c|c|c|c|c|}
\hline Variable & Type & $\begin{array}{l}\text { Number } \\
\text { Observ. }\end{array}$ & Mean & Std. Dev. & Min & $\operatorname{Max}$ \\
\hline Collaboration global & Dummy $1=y e s$ & 105 & 0.462 & 0.500 & 0 & 1 \\
\hline Generation global & Dummy $1=$ yes & 31 & 0.159 & 0.367 & 0 & 1 \\
\hline Standalone & Dummy 1=yes & 169 & 0.871 & 0.336 & 0 & 1 \\
\hline Subsidiary & Dummy $1=y e s$ & 20 & 0.103 & 0.305 & 0 & 1 \\
\hline Headquarter & Dummy 1=yes & 5 & 0.026 & 0.159 & 0 & 1 \\
\hline Size & $\begin{array}{c}\text { Categorical } \\
1=\text { less than } 10 \\
2=10 \text { to } 49 \\
3=50 \text { to } 249 \\
4=250 \text { to } 999 \\
5=\text { more than } 1000\end{array}$ & $\begin{array}{c}63 \\
96 \\
25 \\
7 \\
2\end{array}$ & 1.907 & 0.830 & 1 & 5 \\
\hline R\&D activities & Dummy $1=y e s$ & 89 & 0.468 & 0.500 & 0 & 1 \\
\hline $\begin{array}{l}\text { No. Employees performing } \\
\text { R\&D }\end{array}$ & Numerical & 89 & 5.513 & 7.749 & 0 & 33 \\
\hline $\begin{array}{l}\text { Intramural R\&D (local, } \\
\text { regional, global) }\end{array}$ & Dummy $1=y e s$ & 60 & 0.308 & 0.463 & 0 & 1 \\
\hline Employees university degree & Dummy $1=y e s$ & 181 & 0.928 & 0.259 & 0 & 1 \\
\hline Employees postgraduate degree & Dummy $1=$ yes & 91 & 0.467 & 0.500 & 0 & 1 \\
\hline Service innovation & $\begin{array}{c}\text { Categorical } \\
\text { 1=firm level } \\
2=\text { country level } \\
3=\text { world level }\end{array}$ & $\begin{array}{l}93 \\
28 \\
17\end{array}$ & 1.026 & 0.888 & 0 & 3 \\
\hline Support innovation & $\begin{array}{c}\text { Categorical } \\
1=\text { firm level } \\
2=\text { country level } \\
3=\text { world level }\end{array}$ & $\begin{array}{c}73 \\
15 \\
5\end{array}$ & 0.605 & 0.741 & 0 & 3 \\
\hline Production advance systems & Numerical & 146 & 1.872 & 1.569 & 0 & 5 \\
\hline OEM & $\begin{array}{l}\text { Dummy } 1=\text { yes } \\
\text { if } O E M>50\end{array}$ & 24 & 0.123 & 0.329 & 0 & 1 \\
\hline ODM & $\begin{array}{l}\text { Dummy } 1=\text { yes } \\
\text { if } O D M>50\end{array}$ & 33 & 0.169 & 0.376 & 0 & 1 \\
\hline OBM & $\begin{array}{c}\text { Dummy } 1=\text { yes } \\
\text { if } \mathrm{OBM}>50\end{array}$ & 72 & 0.369 & 0.484 & 0 & 1 \\
\hline
\end{tabular}




\begin{tabular}{lcccccc}
\hline Host region competences & Dummy 1=yes & 6 & 0.031 & 0.173 & 0 & 1 \\
& Categorical & & & & & \\
1 $=$ Tier1 & 75 & 2.062 & 0.912 & 1 & 3 \\
$2=$ Tier2 & 33 & & & & \\
Region TIER & $=$ Tier3 & 87 & & & & \\
\hline
\end{tabular}

\subsection{Case}

To illustrate the complex relationship between competences, global innovation networks and its managerial implications we use a case study in the ICT industry. The firm selection is based on three criteria namely the firm's global presence (particularly presence in China, India, Brazil and South Africa), production and innovation capabilities, innovation leadership and headquartered in Sweden. Due to the request of anonymity of the firm, we use TELEQUIP instead of the real name of the company.

TELEQUIP is a world-leader provider of telecommunications equipment and services. TELEQUIP's main business is the provision of network equipment and services for telecommunication. The R\&D sites (20-25) are in proximity with the main manufacturing units, which indicates a high degree of overlap between the global production network and the global innovation network of TELEQUIP. In terms of locations, TELEQUIP has important R\&D facilities in countries like Germany, Canada, USA (Silicon Valley), Ireland, Hungary and China. Currently the three largest TELEQUIP's R\&D facilities in the world for the radio division are the one in Sweden, the one in the Silicon Valley (USA) and the one in China. The research conducted in TELEQUIP R\&D centers worldwide can be both for the development of a completely new product or service for the whole corporation as well as for the adaptation of an existing product to a local market ${ }^{4}$.

Interviews were conducted in 2010 and 2011 with several CEOs of the company in the Headquarters as well as in the subsidiaries in South Africa and China: the Vice-

\footnotetext{
${ }^{4}$ An example of the development of a local solution for local needs could be the development of radio equipment in rural areas in India that would be conducted completely by TELEQUIP India. Another example of a development in which the subsidiaries will be involved could be a technology developed in US that needs to be adapted to the standards and requirement of the market in which TELEQUIP is commercializing that technology.
} 
president and head of R\&D at Headquaters, the Chief director of TELEQUIP China, the CEO for Commercial management of TELEQUIP Sub-saharan Africa, the Strategy and Marketing director of TELEQUIP Sub-saharan Africa and the CEO of Innovation and partnering of TELEQUIP Sub-saharan Africa. We used the information collected in the different sites to check the validity of the statements (for example, between the headquaters and the subsidiaries). Interviews were semistructured and lasted 2 to 3 hours. All interviews were recorded and transcribed. A document summarizing the most important issues raised in the interview was also produced within 24 hours after the interview. Additional information was collected from the annual reports, website and other public information of the firm.

\section{Globalization of innovation and competences in the Swedish ICT industry}

\subsection{Results of the survey}

The results of the regression equation given in Table 2 show that both firm-level competences as well as regional competences matter for firms engagement in globalization of innovation, but they relate differently for global research collaboration than for global generation of innovation.

In the case of global research collaborations, organizational competences - in this case captured by the availability of advanced production systems- matter most. As expected, the number of employees in $R \& D$ as well as the engagement in intra-mural $\mathrm{R} \& \mathrm{D}$ activities is positively correlated to the engagement of the firm with global research collaboration, as it is directly related to its absorptive capacity. In terms of human capital in general, only the existence of qualified human capital at postgraduate level is significant, which may be related to the importance of $R \& D$ employees. Interestingly enough, size doesn't seem to matter for the propensity of Swedish ICT firms to engage in global research collaboration. This result seem to be in line with data from the Swedish innovation survey which also shows a very high proportion of small (and medium size firms) that report to collaborate for innovation with distant partners such as Indian or Chinese. The competences available at the regional level in Sweden (captured by the variable Region Tier) is not significantly related to global research collaboration. The international orientation of the Swedish business sector (Marklund 2004) is also reflected in their propensity to engage in 
global research collaboration, independently of the firm size or the location of the unit in Sweden.

Table 2. Competences as drivers and enablers of GINs

\begin{tabular}{|c|c|c|}
\hline & $\begin{array}{c}\text { Global } \\
\text { research } \\
\text { collaboration }\end{array}$ & $\begin{array}{c}\text { Global } \\
\text { Generation }\end{array}$ \\
\hline \multicolumn{3}{|l|}{ Firm level competences } \\
\hline \multicolumn{3}{|l|}{ Human Capital } \\
\hline Employees university degree & $\begin{array}{c}0.094 \\
(0.159)\end{array}$ & $\begin{array}{l}-0.089 \\
(0.091)\end{array}$ \\
\hline Employees posgraduate degree & $\begin{array}{l}0.123 * \\
(0.078)\end{array}$ & $\begin{array}{l}0.080 * \\
(0.045)\end{array}$ \\
\hline \multicolumn{3}{|l|}{ R\&D activities } \\
\hline R\&D activities & $\begin{array}{l}-0.139 \\
(0.124)\end{array}$ & $\begin{array}{c}0.026 \\
(0.073)\end{array}$ \\
\hline R\&D employees & $\begin{array}{c}0.017 * * \\
(0.008)\end{array}$ & $\begin{array}{l}-0.005 \\
(0.005)\end{array}$ \\
\hline Intramural R\&D & $\begin{array}{c}0.190 * * \\
(0.096)\end{array}$ & $\begin{array}{c}0.443 * * * \\
(0.055)\end{array}$ \\
\hline \multicolumn{3}{|c|}{ Other organizational competences } \\
\hline Service innovation & & $\begin{array}{c}0.027 \\
(0.026)\end{array}$ \\
\hline Support innovation & & $\begin{array}{c}0.014 \\
(0.031)\end{array}$ \\
\hline Advanced production systems & $\begin{array}{c}0.058 * * \\
(0.027)\end{array}$ & $\begin{array}{c}0.019 \\
(0.016)\end{array}$ \\
\hline OEM & $\begin{array}{c}-0.001 \\
(0.130)\end{array}$ & $\begin{array}{c}-0.002 \\
(0.075)\end{array}$ \\
\hline ODM & $\begin{array}{c}0.058 \\
(0.109)\end{array}$ & $\begin{array}{c}0.173 * * \\
(0.063)\end{array}$ \\
\hline OBM & $\begin{array}{c}0.088 \\
(0.087) \\
\end{array}$ & $\begin{array}{c}-0.010 \\
(0.050) \\
\end{array}$ \\
\hline \multicolumn{3}{|l|}{ Regional competences } \\
\hline Host region competences & & $\begin{array}{c}0.446 * * * \\
(0.116)\end{array}$ \\
\hline Region TIER & $\begin{array}{c}-0.012 \\
(0.044)\end{array}$ & $\begin{array}{c}0.055^{* *} \\
(0.025) \\
\end{array}$ \\
\hline \multicolumn{3}{|l|}{ Other firm characteristics } \\
\hline Standalone & $\begin{array}{c}0.144 \\
(0.128)\end{array}$ & \\
\hline Subsidiary & & $\begin{array}{c}-0.026 \\
(0.074)\end{array}$ \\
\hline mnc & $\begin{array}{l}-0.159 \\
(0.276)\end{array}$ & $\begin{array}{c}0.108 \\
(0.151)\end{array}$ \\
\hline Size & $\begin{array}{c}0.007 \\
(0.056)\end{array}$ & $\begin{array}{c}0.035 \\
(0.032)\end{array}$ \\
\hline R-squared & 0.176 & 0.499 \\
\hline
\end{tabular}

Note: ${ }^{* * *},{ }^{* *},{ }^{*}$ indicate significance at the $1 \%, 5 \%$ and $10 \%$ level respectively. Standard errors in parenthesis. 
Both firm level competences and regional competences are related to the propensity of Swedish ICT firms to engage in global generation of innovation (or offshoring of innovation activities). At firm level, the qualification of human capital, the engagement in $R \& D$ activities and the existence of other organizational competences are positively related to offshoring of innovation, although with different degree. Conducting intramural $R \& D$ activities is highly significant for offshoring of innovation, as it may be expected. So it is if the firm is producing and designing products according to the performance requirements of buyers (ODM) but not if the firm is an OBM or OEM. The qualification of the human capital is also significant, but to a lesser extent. As in the case of global research collaboration, the size of firm is not significant. The results also confirm that competences are a very important driver for the global generation of innovation. The availability of knowledge in the host region and the Region Tier are highly correlated to this form of GIN thus pointing out to the importance of asset seeking strategies in the process of globalization of innovation of Swedish ICT firms. What the survey does not tell us is how competences are related to the specific form of innovation activities that are offshored or how competences are managed within a specific multinational company. A case study can provide some insights into these issues.

\subsection{Competences and globalization of innovation to emerging economies: the case of TELEQUIP}

The case of TELEQUIP is interesting to illustrate how different competences accumulated in specific regions in emerging economies are shaping the decision of a multinational company to locate innovation activities worldwide.

In the past 10 years the number of European sites of TELEQUIP has declined to gain more efficiency. According to one of the interviewee: "small sites with 100-200 people are not attractive places for people as they do not grow". While the number of sites in Europe has decreased, the presence in USA remained unchanged while new R\&D sites within the emerging economies, like India and China were opened. 
In general, the R\&D activities and the most specialized competences (in the internal network) remain concentrated in the sites located in Europe and USA but, according to the Vice-president R\&D China has upgraded rapidly as an important R\&D site inside TELEQUIP. The reason for this move towards large Asian economies is related to being in proximity to the local market and adaptation of the products to the local demands and standards but access to competences and more explicitly, access to "domain competences" is regarded as the second main driver for the location of R\&D activities abroad.

In the last decade or so, TELEQUIP has followed a clear strategy of reducing the number of R\&D sites worldwide while increasing the size of the remaining sites (less sites bur larger ones). This has occurred in parallel with the increasing technological complexity of ICT products and services, which demands a larger variety of skills (from software developers, to radio experts, computer engineers, etc). Different subsidiaries play a very different role in the global innovation strategy of the company depending on their competence level. Each of the largest R\&D sites of TELEQUIP sites has specialized in a particular knowledge domain. For example, the site in the Silicon Valley (USA) has the R\&D site for radio products, as the site in China and India is strong in IT which is related to TELEQUIP Internet Protocol (IP) business.

\section{China}

Accessing domain competences is one of the main drivers for TELEQUIP to locate one of the largest corporate R\&D sites in China, but is not the only one. When asked if they would change their strategy if they could find the required number of skilled people with the desired qualifications in Sweden, our interviewee responded that they would not change their strategy, as the main driver for locating the R\&D lab in China continues to be the access to one of their largest markets and the development of products and services for that market. So, it is a combination of large market opportunities together with the availability of highly qualified personnel at a lower cost what makes China (and more precisely Beijing) one of the most important locations of R\&D sites in TELEQUIP.

The location in particular regions also facilitates close interactions with universities and research centers. The interviewee with the Operation Development Director of 
TELEQUIP in China regards the large pool of skilled people coming from various Chinese universities as a main reason for locating the R\&D sites in this country and in particular regions. For example, the Nanjing centre has been started due to presence of regional actors, being universities and colleges, as well as TELEQUIP's biggest manufacturing unit. In his view there are not many differences between the Chinese market and markets in rest of the world which makes it easier for the subsidiary to provide solutions for the entire company. In his words: "Our market strategy is to provide global solutions, and solve problems in terms of network smooth and call quality, whether what we face is high-end markets or low-end markets".

The division of labor in terms of innovation between the HQ and the subsidiary is better explained by the CEO of TELEQUIP in Sweden. He indicates that "For the activities related to Radio based stations the most important innovations are the ones that are developed in Sweden, Canada and China but Sweden does mainly core innovation while in China the activities are mainly related to the implementation of idea. The Chinese subsidiary can be relevant, for example, for incremental innovation (e.g. reducing cost and adapting the product to the specific profile of Chinese operators). But some of those innovations also have a global effect. An example of incremental innovation with a 'global' effect is the production of a play station adapted to the local context; this idea is starting now to be spread worldwide". This possibility of the subsidiaries to develop solutions potentially useful for the entire corporation puts an additional emphasis on the competences in the subsidiaries. There are not merely adapting the products to the local market, but developing products or services (sometimes brand new) that are potentially useful for the entire corporation.

\section{India}

TELEQUIP has a subsidiary in Bangalore. According to the vice-president R\&D the Indian subsidiary can be regarded as strong within the IT area but the Chinese have a broader range of domain competences in many different areas and thus conduct research for different business in TELEQUIP. So R\&D in India is narrower than in China not because the Indian market demands fewer or less sophisticated products, but because they don't have all the requisite competences. Especially since TELEQUIP -as a group- benefits from what goes on in its Chinese operation in that it generates knowledge and equipment for global markets, competences rather than 
market proximity seem to matter more. So, it is the breadth and depth of skills available in China what makes the Chinese site a more interesting location for R\&D for TELEQUIP than India.

\section{South Africa}

The subsidiary of TELEQUIP in South Africa aims at adapting TELEQUIP products for the African market. The subsidiary does not have its own R\&D department. The interviews done by one of our partners in South Africa may provide some insights ${ }^{5}$ of why this is so. A CEO of TELEQUIP Sub-saharan Africa explains that the reasons behind a lack of R\&D site in SA are related to size of market (smaller than that of China and India for example) and the lack of skilled labor or specific expertise in certain competences. He emphasizes the lack of engineers as a main hindrance for TELEQUIP in SA. The Commercial Management of TELEQUIP in Subsaharan Africa also talks about reasons for choosing India and China as the R\&D sites and he mainly refers to the issue of a large pool of skilled labour at a reasonable price. In his words: "R\&D price is still quite high and to do it we have to look at the centres that provide engineering expertise and efficiency. And also at a very low cost. And India and China provide those fundamentals". Further on he refers to the fact that in the case of China the products can also be supplied at a global level, thus confirming what the interviewee in the headquarter said.

The role of the South African subsidiary in the global strategy of TELEQUIP is related to the adaptation of the products to the African market. For doing so, knowledge of the local languages is essential. As one of the interviewees in South Africa indicates "as more and more people get into the mobile arena with handsets and so on, the local languages become more important". Therefore in order to penetrate the whole Africa it is a necessity to have skilled people from African regions. He indicates that even though the headquaters have the knowledge on networks they need to have a better understanding of the local consumers.

\footnotetext{
${ }^{5}$ Interviews were conducted by Tashmia Ismail and Helena Barnard, Gordon Institute of Busines Studies (GIBS), Pretoria University, South Africa. The authors of this paper had access to the transcription of the interviews.
} 
The interviews held in Sweden, China and South Africa point out to a kind of division of labor of offshoring sites in TELEQUIP according to competences. It also shows the interplay between firm level competences and regional competences as enablers and drivers of innovation.

Table 3. Competences and the role of different sites in the global innovation strategy of TELEQUIP

\begin{tabular}{|c|c|c|}
\hline Sites & Competences & Role \\
\hline Sweden (Headquarter) & $\begin{array}{l}\text { Advanced } R \& D \text { competences in a } \\
\text { variety of domains }\end{array}$ & Core innovation \\
\hline China (Beijing) & $\begin{array}{l}\text { Broad domain competences in radio } \\
\text { communication }\end{array}$ & $\begin{array}{l}\text { Provide solutions for the entire } \\
\text { company (e.g. play station) } \\
\text { Implementation of core } \\
\text { innovations developed at the } \\
\text { headquarter }\end{array}$ \\
\hline India (Bangalore) & $\begin{array}{l}\text { Strong competences in } \begin{array}{r}\text { internet } \\
\text { protocol business } \\
\text { (specific }\end{array} \\
\text { competences in certain domain) }\end{array}$ & $\begin{array}{l}\text { Provide solutions for the entire } \\
\text { company but only in the specific } \\
\text { domain of IP }\end{array}$ \\
\hline South Africa (Gauteng) & Local languages & $\begin{array}{l}\text { Simple adaptation of services to } \\
\text { local market }\end{array}$ \\
\hline
\end{tabular}

Core R\&D seems to be conducted barely in three sites worldwide in Sweden, USA and China. These centers provide complex R\&D solutions for the different business and for the entire corporation which requires a combination of a wide arrange of skills. A second tier of centers are those that provide very specific competences in certain domain, like for example the R\&D center in Bangalore which provides very deep expertise in software. They are also global, in the sense that they provide solutions also to the entire company, but only on specific domains. A final tier of centers are those that conduct mainly development for the local markets. Finally, there are locations in which there are not yet any R\&D center, but only production and sales, with small adaptations to local markets.

\section{Conclusions}


The ICT industry is probably one of the most globalized ones. It is also one in which emerging economies have started to play a very prominent role. While the accumulation of competences in some regions in emerging economies may explain the location choice (competences as a driver) it is very limited to explain how can companies globalize their innovation activities in the first place, that is, which firmlevel competences are necessary to engage in global research collaboration or global generations of innovation through offshoring.

By distinguishing between competences as an enabler and competences as a driver this paper contributes to our understanding of the role of firm and regional competences in the globalization of innovation.

For Swedish ICT firms, the level of competences in the region where the firm is located (home region) and the level of the competences in the host region are related to the propensity of the firm to engage in generation of innovation. The level of competences at firm level is related to both global research collaboration and global generation of innovation. The involvement of the firm in R\&D activities is correlated both with global research collaboration and with global generation of innovation, as it increases not only the innovative capability of the firm but also the capacity to tap into and absorb knowledge from external sources (Cohen and Levinthal, 1990). Global research collaboration is also related to organizational competences particularly the level of flexibility and quality of the processes within the firm. Engaging external sources in the innovation process is necessary but also costly. Having advanced production systems in place may help to standardize some of the processes thus reducing the transaction costs involved in open innovation. Thus firmlevel competences are an important enabler for the globalization of innovation, while home regional competences are only for the global generation of innovation.

The results of the survey also confirm that competences accumulated in the host region are an important driver for the globalization of innovation and in particular for the global generation of innovation. Furthermore, as the case illustrates, the type of innovation activity that is being offshored and the role that the subsidiary plays in the global innovation strategy of the company is highly dependent on the breath and 
depth of the competences available in the host region. While some subsidiaries may be able to play a double role adapting existing products to the local market and developing new solutions for the global markets, others may only play a limited role.

The case of TELEQUIP also points out that there is not one single reason why a company decides to locate an $\mathrm{R} \& \mathrm{D}$ lab in a certain country or region. It is a combination of factors that include firm strategy, environmental conditions and the characteristics of the potential locations in terms of markets and skill supply. In terms of the strategy, TELEQUIP's selection of the sites seems to respond to a double strategy: some of the sites have been selected because they have excel in very specific competences (like Bangalore in India or Ireland) while some others are a combination of the willingness to position themselves in a larger market (also in India) while accessing a broader base of domain competences (Beijing).

Acknowledgements: Research for this paper was partially funded by the European Community's Seventh Framework Programme (Project INGINEUS, Grant Agreement No.225368, www.ingineus.eu). The authors alone are responsible for its contents which do not necessarily reflect the views or opinions of the European Commission, nor is the European Commission responsible for any use that might be made of the information appearing herein. Additionally, financial support from the Swedish Research Council (Linneaus grant) is acknowledged. We would like to thank specially our partners in South Africa - Tashmia Ismail and Prof. Helena Barnardfrom GIBS, University of Pretoria for the interviews they conducted in the subsidiaries of TELEQUIP in South Africa. All errors are exclusively of the authors.

\section{References}

Altenburg, T., H. Schmitz, et al. (2008). "Breakthrough? China's and India's Transition from Production to Innovation." World Development 36(2).

Archibugi, D. and J. Michie (1995). "The globalisation of technology: a new taxonomy." Cambridge Journal of Economics 19(1): 121. 
Arora, A., V. S. Arunachalam, et al. (2001). "The Indian Software Industry." Research Policy 30(2001): 1267-1287.

Arora, A. and A. Gambardella (2004). The globalization of the software industry: perspective and opportunities for developed and developing countries. NBER Working Paper Series.

Arora, A. and A. Gambardella (2005). From Underdogs to Tigers: The Rise and Growth of the Software Industry in Brazil, China, India, Ireland, and Israel, Oxford University Press.

Arora, A., A. Gambardella, et al. (2001). In the Footsteps of Silicon Valley? Indian and Irish Software in the International Division of Labour. SIEPR Discussion Paper No. 00-41. Stanford, Stanford Institute for Economic Policy Research: 38.

Arora, A. B., S. (2006). The Indian Software Industry: the Human Capital Story. DRUID.

Asheim, B. T. and A. Isaksen (1997). "Location, agglomeration and innovation: towards regional innovation systems in Norway?" European Planning Studies 5(3): 299-330.

Audretsch, D. B. and M. P. Feldman (1996). "R\&D spillovers and the geography of innovation and production." The American Economic Review 86(3): 630-640.

Barney, J., M. Wright, et al. (2001). "The resource-based view of the firm: Ten years after 1991." Journal of Management 27(6): 625.

Barney, J. B. (1996). "The Resource-Based Theory of the Firm." Organization Science 7(5): 469-469.

Bathelt, H. and J. Glûckler (2003). "Toward a relational economic geography." Journal of Economic Geography 3: 117-144.

Bell, M. and K. Pavitt (1995). "The Development of Technological Capabilities." Trade, Technology and International Competitiveness: 69-101.

Burt, R. S. (1992). Structural holes. Cambridge, Cambridge University Press.

Castellacci, F. and D. Archibugi (2008). "The technology clubs: The distribution of knowledge across nations." Research Policy 37(10): 1659-1673.

Chaminade, C. (2009). "On the concept of global innovation networks." CIRCLE Electronic Working paper 2009/05.

Chaminade, C. and J. Vang (2008). "Globalisation of knowledge production and regional innovation policy: Supporting specialized hubs in the Bangalore software industry." Research Policy 37(10): 1684-1696.

Coe, N., P. Dicken, et al. (2004). "Global production networks: realizing the potential." Journal of Economic Geography 8: 271-295. 
Cohen, W. and D. Levinthal (1990). "Absorptive capacity: a new perspective on learning and innovation." Administrative Science Quarterly 35: 128-152.

Cooke, P. (1992). "Regional innovation systems: competitive regulation in the new Europe." Geoforum 23(3): 365-382.

De Bresson, C. and F. Amesse (1991). "Networks of innovators : a review and introduction to the issue." Research Policy 20(5): 363-379.

Dickens, P. (2007). Global Shifts: mapping the changing contours of the world economy. New York, Guilford.

Dunning, J. H. (1993). Trade, Location of Economic Activity and the Multinational Enterprise: A Search for an Eclectic Approach, Routledge.

Dunning, J. H. (2001). "The Eclectic (OLI) Paradigm of International Production: Past, Present and Future." Int. J. of the Economics of Business 8(2): 173-190.

Dunning, J. H. and R. Narula (1995). "The R\&D activities of foreign firms in the United States." International Studies of Management \& Organization 25(1/2): 39-74.

Dunning, J. H., R. Narula, et al. (1997). "Explaining the new wave of outward FDI from developing countries: the case of Taiwan and Corea." International Business Review.

Eisenhardt, K. and J. Martin (2000). "Dynamic capabilities; what are they?" Strategic Management Journal 21(9): 1105-1121.

Freeman, C. (1987). Technology policy and economic performance: lessons from Japan. London, Pinter.

Freeman, C. (1991). "Networks of innovators: a synthesis of research issues." Research Policy 20(5): 499-514.

Gereffi, G., Humphrey, J., Sturgeon, T. (2005). "The governance of global value chains." Review of International Political Economy 12(1): 78-104.

Giuliani, E. (2007). "The selective nature of knowledge networks in clusters: evidence from the wine industry." Journal of Economic Geography 7(2): 139-168.

Giuliani, E. and M. Bell (2005). "When micro shapes the meso: Learning networks in a Chilean wine cluster." Research Policy 34(1): 47-68.

Grant, R. (1991). "The resource-based theory of competitive advantage: implications for strategy formulation." California Management Review spring: 114-135.

Howells, J. (1990). "The internationalization of R \& D and the development of global research networks." Regional Studies 24(6): 495-512.

Humphrey, J. and H. Schmitz (2002). "How does insertion in global value chains affect upgrading in industrial clusters?" Regional Studies 36(9): 1017-1027. 
Knight, G. A. and S. T. Cavusgil (2004). "Innovation, Organizational Capabilities, and the Born-Global Firm." Journal of International Business Studies 35(2): 124-141.

Lall, S. (1992). "Technological capabilities and industrialization." World Development 20(2): 165-186.

Li, J. J., L. Poppo, et al. (2010). "Relational mechanisms, formal contracts, and local knowledge acquisition by international subsidiaries." Strategic Management Journal 31(4): 349-370.

Lundvall, B.-A. (1988). Innovation as an interactive process: from user-producer interaction to the national system of innovation. Technical change and economic theory. G. E. A. Dosi. London, Pinter.

Lundvall, B.-A. (1992). User-producer relationships, national systems of innovation and internalization. National systems of innovation. Towards a theory of innovation and interactive learning. B.-Ä. Lundvall. London, Pinter: 45-67.

Marklund, G., Nilsson, R., Sandgren, P., Granat Thorslund, J., Ullström, J. (2004). The Swedish national Innovation system 1970-2003. A quantitative international benchmarking analysis. VINNOVA ANALYSIS VA 2004:1.

Martin, R. and J. Moodysson (2011). "Innovation in Symbolic Industries: The Geography and Organization of Knowledge Sourcing." European Planning Studies 19(7): 1183-1203.

Moodysson, J. (2008). "Principles and Practices of Knowledge Creation: On the Organization of" Buzz" and" Pipelines" in Life Science Communities." Economic Geography 84(4): 449-469.

Moodysson, J., L. Coenen, et al. (2008). "Explaining spatial patterns of innovation: analytical and synthetic modes of knowledge creation in the Medicon Valley lifescience cluster." Environment and Planning A 40(5): 1040-1056.

Mothe, J. D. L. and G. Paquet, Eds. (1998). Local and regional systems of innovation. Norwell, Kluwer Academic Publishers.

Narula, R. and A. Zanfei (2004). Globalization of innovation: the role of multinational enterprises. The Oxford Handbook of Innovation. J. Fagerberg, D. Mowery and R. Nelson. Oxford, OUP: 318-347.

Nooteboom, B. (2000). "Learning by Interaction: Absorptive Capacity, Cognitive Distance and Governance." Journal of Management and Governance 4: 69-92.

Nooteboom, B. (2003). Learning and governance in inter-firm relations.

Nooteboom, B. (2004). Inter-firm collaboration, learning and networks. An integrated approach. London and New York, Routledge.

Nooteboom, B., W. Van Haverbeke, et al. (2007). "Optimal cognitive distance and absorptive capacity." Research Policy 36(7): 1016-1034. 
Partharasarathy, B. and Y. Aoyama (2006). "From software services to R\&D services: local entrepreneurship in the software industry in Bangalore, India." Environment and Planning 38: 1269-1285.

Parthasarathy, B. and Y. Aoyama (2006). "From software services to R\&D services: Local entrepreneurship in the software industry in Bangalore, India." Environment and Planning A 38: 1269-1285.

Powell, W. W. and S. Grodal (2004). Networks of innovators. The Oxford Handbook of Innovation. J. Fagerberg, D. Mowery and R. Nelson. Oxford, OUP: 1-29.

Sabiola, F. and A. Zanfei (2009). "Multinational firms, global value chains and the organization of knowledge transfer." Research Policy 38: 369-381.

Saxenian, A.-L. (2001). Bangalore: the Silicon Valley of Asia? Centre for Research on Economic Development and Policy Reform, Berkeley University.

Saxenian, A. L. (2001). Bangalore: The Silicon Valley of Asia? Working Paper. Tanford, Center for Research on Economic Development and Policy Reform: 32.

Sousa, C. M. P., F. J. Martínez- López, et al. (2008). "The determinants of export performance: A review of the research in the literature between 1998 and 2005." International Journal of Management Reviews 10(4): 343-374.

Teece, D. J. (1980). "Economies of scope and the scope of the enterprise." Journal of Economic Behavior and Organization 1(3): 223-247.

Unctad (2006). World Investment Report. FDI from Developing and Transition Economies: Implications for Development,

Wernefelt, B. (1984). "A resource-based view of the firm." Strategic Management Journal 5(10): 171-180.

Zander, I. (1999). "How do you mean [l global'? An empirical investigation of innovation networks in the multinational corporation." Research Policy 28(2-3): 195213.

Zanfei, A. (2000). "Transnational firms and the changing organisation of innovative activities." Cambridge Journal of Economics 24: 515-542. 


\section{CIRCLE ELECTRONIC WORKING PAPERS SERIES (EWP)}

CIRCLE (Centre for Innovation, Research and Competence in the Learning Economy) is a multidisciplinary research centre set off by several faculties at Lund University and Blekinge Institute of Technology. CIRCLE has a mandate to conduct multidisciplinary research and education on the following issues: Long-term perspectives on innovation, structural change and economic growth, Entrepreneurship and venture capital formation with a special focus on new ventures, The dynamics of R\&D systems and technological systems, including their impact on entrepreneurship and growth, Regional innovation systems in different national and international contexts and International comparative analyses of national innovation systems. Special emphasis is done on innovation policies and research policies. 10 nationalities and 14 disciplines are represented among the CIRCLE staff.

The CIRCLE Electronic Working Paper Series are intended to be an instrument for early dissemination of the research undertaken by CIRCLE researchers, associates and visiting scholars and stimulate discussion and critical comment.

The working papers present research results that in whole or in part are suitable for submission to a refereed journal or to the editor of a book or have already been submitted and/or accepted for publication.

CIRCLE EWPs are available on-line at: http://www.circle.lu.se/publications

Available papers:

2012

WP 2012/01

Is the University Model an Organizational Necessity? Scale and Agglomeration Effects in Science

Tasso Brandt and Torben Schubert

WP 2012/02

Do regions make a difference? Exploring the role of different regional innovation systems in global innovation networks in the ICT industry

Cristina Chaminade and Monica Plechero

WP 2012/03

Measuring the knowledge base of regional innovation systems in Sweden Roman Martin

WP 2012/04

Characteristics and Performance of New Firms and Spinoffs in Sweden Martin Andersson and Steven Klepper

WP 2012/05

Demographic patterns and trends in patenting: Gender, age, and education of inventors

Olof Ejermo and Taehyun Jung

WP 2012/06

Competences as drivers and enablers of globalization of innovation: Swedish ICT industry and emerging economies

Cristina Chaminade and Claudia de Fuentes 
WP 2011/01

SMEs' absorptive capacities and large firms' knowledge spillovers: Micro evidence from Mexico

Claudia de Fuentes and Gabriela Dutrénit

WP 2011/02

Comparing knowledge bases: on the organisation and geography of knowledge flows in the regional innovation system of Scania, southern Sweden Roman Martin and Jerker Moodysson

WP 2011/03

Organizational paths of commercializing patented inventions: The effects of transaction costs, firm capabilities, and collaborative ties

Taehyun Jung and John P. Walsh

WP 2011/04

Global Innovation Networks: towards a taxonomy

Helena Barnard and Cristina Chaminade

WP 2011/05

Swedish Business R\&D and its Export Dependence

Karin Bergman and Olof Ejermo

WP 2011/06

Innovation Policy Design: Identification of Systemic Problems

Charles Edquist

WP 2011/07

Regional Institutional Environment and Its Impact on Intra-firm and Interorganisational

Innovation Networks: A Comparative Case Study in China and

Switzerland

Ju LIU

WP 2011/08

Entrepreneurship: Exploring the Knowledge Base

Hans Landström, Gouya Harirchi and Fredrik Åström

WP 2011/09

Policy coordination in systems of innovation: A structural-functional analysis of regional industry support in Sweden

Magnus Nilsson and Jerker Moodysson

WP 2011/10

Urban Design in Neighbourhood Commodification

Ana Mafalda Madureira

WP 2011/11

Technological Dynamics and Social Capability: Comparing U.S. States and European Nations

Jan Fagerberg, Maryan Feldman and Martin Srhoelec 
WP 2011/12

Linking scientific and practical knowledge in innovation systems

Arne Isaksen and Magnus Nilsson

WP 2011/13

Institutional conditions and innovation systems: on the impact of regional policy on firms in different sectors

Jerker Moodysson and Elena Zukauskaite

WP 2011/14

Considering adoption: Towards a consumption-oriented approach to innovation

Josephine V. Rekers

WP2011/15

Exploring the role of regional innovation systems and institutions in global innovation networks

Cristina Chaminade

2010

WP 2010/01

Innovation policies for development: towards a systemic experimentation based approach

Cristina Chaminade, Bengt-Ake Lundvall, Jan Vang-Lauridsen and KJ Joseph

WP 2010/02

From Basic Research to Innovation: Entrepreneurial Intermediaries for Research Commercialization at Swedish 'Strong Research Environments'

Fumi Kitagawa and Caroline Wigren

WP 2010/03 Different competences, different modes in the globalization of innovation?

A comparative study of the Pune and Beijing regions

Monica Plechero and Cristina Chaminade

WP 2010/04 Technological Capability Building in Informal Firms in the Agricultural

Subsistence Sector In Tanzania: Assessing the Role of Gatsby Clubs

Astrid Szogs and Kelefa Mwantima

WP 2010/05

The Swedish Paradox - Unexploited Opportunities!

Charles Edquist

WP 2010/06

A three-stage model of the Academy-Industry linking process: the perspective of both agents

Claudia De Fuentes and Gabriela Dutrénit

WP 2010/07

Innovation in symbolic industries: the geography and organisation of knowledge sourcing

Roman Martin and Jerker Moodysson 
WP 2010/08

Towards a spatial perspective on sustainability transitions

Lars Coenen, Paul Benneworth and Bernhard Truffer

WP 2010/09

The Swedish national innovation system and its relevance for the emergence of global innovation networks

Cristina Chaminade, Jon Mikel Zabala and Adele Treccani

WP 2010/10

Who leads Research Productivity Change? Guidelines for R\&D policy makers Fernando Jiménez-Sáez, Jon Mikel Zabala and José L- Zofío

WP 2010/11

Research councils facing new science and technology

Frank van der Most and Barend van der Meulen

WP 2010/12

From new to the firm to new to the world. Effect of geographical proximity and technological capabilities on the degree of novelty in emerging economies Monica Plechero and Cristina Chaminade

WP 2010/13

Are knowledge-bases enough? A comparative study of the geography of knowledge sources in China (Great Beijing) and India (Pune)

Cristina Chaminade

WP 2010/14

Regional Innovation Policy beyond 'Best Practice': Lessons from Sweden Roman Martin, Jerker Moodysson and Elena Zukauskaite

WP 2010/15

Innovation in cultural industries: The role of university links

Elena Zukauskaite

WP 2010/16

Use and non-use of research evaluation. A literature review

Frank van der Most

WP 2010/17

Upscaling emerging niche technologies in sustainable energy: an international comparison of policy approaches

Lars Coenen, Roald Suurs and Emma van Sandick

2009

WP 2009/01

Building systems of innovation in less developed countries: The role of intermediate organizations.

Szogs, Astrid; Cummings, Andrew and Chaminade, Cristina 
WP 2009/02

The Widening and Deepening of Innovation Policy: What Conditions Provide for Effective Governance?

Borrás, Susana

WP 2009/03

Managerial learning and development in small firms: implications based on observations of managerial work

Gabrielsson, Jonas and Tell, Joakim

WP 2009/04

University professors and research commercialization: An empirical test of the "knowledge corridor" thesis

Gabrielsson, Jonas, Politis, Diamanto and Tell, Joakim

WP 2009/05

On the concept of global innovation networks

Chaminade, Cristina

WP 2009/06

Technological Waves and Economic Growth - Sweden in an International Perspective 1850-2005

Schön, Lennart

WP 2009/07

Public Procurement of Innovation Diffusion: Exploring the Role of Institutions and Institutional Coordination

Rolfstam, Max; Phillips, Wendy and Bakker, Elmer

WP 2009/08

Local niche experimentation in energy transitions: a theoretical and empirical exploration of proximity advantages and disadvantages

Lars Coenen, Rob Raven, Geert Verbong

WP 2009/9

Product Development Decisions: An empirical approach to Krishnan and Ulrich Jon Mikel Zabala, Tina Hannemann

WP 2009/10

Dynamics of a Technological Innovator Network and its impact on technological performance

Ju Liu, Cristina Chaminade

WP 2009/11

The Role of Local Universities in Improving Traditional SMEs Innovative Performances: The Veneto Region Case

Monica Plechero

WP 2009/12

Comparing systems approaches to innovation and technological change for sustainable and competitive economies: an explorative study into conceptual commonalities, differences and complementarities

Coenen, Lars and Díaz López, Fernando J. 
WP 2009/13

Public Procurement for Innovation (PPI) - a Pilot Study

Charles Edquist

WP 2009/14

Outputs of innovation systems: a European perspective

Charles Edquist and Jon Mikel Zabala

2008

WP 2008/01

$R \& D$ and financial systems: the determinants of $R \& D$ expenditures in the Swedish pharmaceutical industry

Malmberg, Claes

WP 2008/02

The Development of a New Swedish Innovation Policy. A Historical Institutional Approach

Persson, Bo

WP 2008/03

The Effects of R\&D on Regional Invention and Innovation

Olof Ejermo and Urban Gråsjö

WP 2008/04

Clusters in Time and Space: Understanding the Growth and Transformation of Life Science in Scania

Moodysson, Jerker; Nilsson, Magnus; Svensson Henning, Martin

WP 2008/05

Building absorptive capacity in less developed countries

The case of Tanzania

Szogs, Astrid; Chaminade, Cristina and Azatyan, Ruzana

WP 2008/06

Design of Innovation Policy through Diagnostic Analysis:

Identification of Systemic Problems (or Failures)

Edquist, Charles

WP 2008/07

The Swedish Paradox arises in Fast-Growing Sectors

Ejermo, Olof; Kander, Astrid and Svensson Henning, Martin

WP 2008/08

Policy Reforms, New University-Industry Links and Implications for Regional Development in Japan

Kitagawa, Fumi

WP 2008/09

The Challenges of Globalisation: Strategic Choices for Innovation Policy

Borrás, Susana; Chaminade, Cristina and Edquist, Charles 
WP 2008/10

Comparing national systems of innovation in Asia and Europe: theory and comparative framework

Edquist, Charles and Hommen, Leif

WP 2008/11

Putting Constructed Regional Advantage into Swedish Practice? The case of the VINNVÄXT initiative 'Food Innovation at Interfaces'

Coenen, Lars; Moodysson, Jerker

WP 2008/12

Energy transitions in Europe: 1600-2000

Kander, Astrid; Malanima, Paolo and Warde, Paul

WP 2008/13

RIS and Developing Countries: Linking firm technological capabilities to regional systems of innovation

Padilla, Ramon; Vang, Jan and Chaminade, Cristina

WP 2008/14

The paradox of high R\&D input and low innovation output: Sweden

Bitarre, Pierre; Edquist, Charles; Hommen, Leif and Ricke, Annika

WP 2008/15

Two Sides of the Same Coin? Local and Global Knowledge Flows in Medicon Valley

Moodysson, Jerker; Coenen, Lars and Asheim, Bjørn

WP 2008/16

Electrification and energy productivity

Enflo, Kerstin; Kander, Astrid and Schön, Lennart

WP 2008/17

Concluding Chapter: Globalisation and Innovation Policy

Hommen, Leif and Edquist, Charles

WP 2008/18

Regional innovation systems and the global location of innovation activities: Lessons from China

Yun-Chung, Chen; Vang, Jan and Chaminade, Cristina

WP 2008/19

The Role of mediator organisations in the making of innovation systems in least developed countries. Evidence from Tanzania

Szogs, Astrid

WP 2008/20

Globalisation of Knowledge Production and Regional Innovation Policy:

Supporting Specialized Hubs in the Bangalore Software Industry

Chaminade, Cristina and Vang, Jan

WP 2008/21

Upgrading in Asian clusters: Rethinking the importance of interactive-learning 
Chaminade, Cristina and Vang, Jan

2007

WP 2007/01

Path-following or Leapfrogging in Catching-up: the Case of Chinese Telecommunication Equipment Industry

Liu, Xielin

WP 2007/02

The effects of institutional change on innovation and productivity growth in the Swedish pharmaceutical industry

Malmberg, Claes

WP 2007/03

Global-local linkages, Spillovers and Cultural Clusters: Theoretical and Empirical insights from an exploratory study of Toronto's Film Cluster

Vang, Jan; Chaminade, Cristina

WP 2007/04

Learning from the Bangalore Experience: The Role of Universities in an Emerging Regional Innovation System

Vang, Jan; Chaminade, Cristina.; Coenen, Lars.

WP 2007/05

Industrial dynamics and innovative pressure on energy -Sweden with European and Global outlooks

Schön, Lennart; Kander, Astrid.

WP 2007/06

In defence of electricity as a general purpose technology

Kander, Astrid; Enflo, Kerstin; Schön, Lennart

WP 2007/07

Swedish business research productivity - improvements against international trends

Ejermo, Olof; Kander, Astrid

WP 2007/08

Regional innovation measured by patent data - does quality matter?

Ejermo, Olof

WP 2007/09

Innovation System Policies in Less Successful Developing countries: The case of Thailand

Intarakumnerd, Patarapong; Chaminade, Cristina

2006

WP 2006/01

The Swedish Paradox

Ejermo, Olof; Kander, Astrid 
WP 2006/02

Building RIS in Developing Countries: Policy Lessons from Bangalore, India Vang, Jan; Chaminade, Cristina

WP 2006/03

Innovation Policy for Asian SMEs: Exploring cluster differences

Chaminade, Cristina; Vang, Jan.

WP 2006/04

Rationales for public intervention from a system of innovation approach: the case of VINNOVA.

Chaminade, Cristina; Edquist, Charles

WP 2006/05

Technology and Trade: an analysis of technology specialization and export flows

Andersson, Martin; Ejermo, Olof

WP 2006/06

A Knowledge-based Categorization of Research-based Spin-off Creation

Gabrielsson, Jonas; Landström, Hans; Brunsnes, E. Thomas

WP 2006/07

Board control and corporate innovation: an empirical study of small technology-based firms

Gabrielsson, Jonas; Politis, Diamanto

WP 2006/08

On and Off the Beaten Path:

Transferring Knowledge through Formal and Informal Networks

Rick Aalbers; Otto Koppius; Wilfred Dolfsma

WP 2006/09

Trends in R\&D, innovation and productivity in Sweden 1985-2002

Ejermo, Olof; Kander, Astrid

WP 2006/10

Development Blocks and the Second Industrial Revolution, Sweden 1900-1974

Enflo, Kerstin; Kander, Astrid; Schön, Lennart

WP 2006/11

The uneven and selective nature of cluster knowledge networks: evidence from the wine industry

Giuliani, Elisa

WP 2006/12

Informal investors and value added: The contribution of investors' experientially acquired resources in the entrepreneurial process

Politis, Diamanto; Gabrielsson, Jonas

WP 2006/13

Informal investors and value added: What do we know and where do we go?

Politis, Diamanto; Gabrielsson, Jonas 
WP 2006/14

Inventive and innovative activity over time and geographical space: the case of Sweden

Ejermo, Olof

2005

WP 2005/1

Constructing Regional Advantage at the Northern Edge

Coenen, Lars; Asheim, Bjørn

WP 2005/02

From Theory to Practice: The Use of the Systems of Innovation Approach for Innovation Policy

Chaminade, Cristina; Edquist, Charles

WP 2005/03

The Role of Regional Innovation Systems in a Globalising Economy: Comparing Knowledge Bases and Institutional Frameworks in Nordic Clusters Asheim, Bjørn; Coenen, Lars

WP 2005/04

How does Accessibility to Knowledge Sources Affect the Innovativeness of Corporations? Evidence from Sweden

Andersson, Martin; Ejermo, Olof

WP 2005/05

Contextualizing Regional Innovation Systems in a Globalizing Learning Economy: On Knowledge Bases and Institutional Frameworks

Asheim, Bjørn; Coenen, Lars

WP 2005/06

Innovation Policies for Asian SMEs: An Innovation Systems Perspective

Chaminade, Cristina; Vang, Jan

WP 2005/07

Re-norming the Science-Society Relation

Jacob, Merle

WP 2005/08

Corporate innovation and competitive environment

Huse, Morten; Neubaum, Donald O.; Gabrielsson, Jonas

WP 2005/09

Knowledge and accountability: Outside directors' contribution in the corporate value chain

Huse, Morten, Gabrielsson, Jonas; Minichilli, Alessandro

WP 2005/10

Rethinking the Spatial Organization of Creative Industries

Vang, Jan

WP 2005/11

Interregional Inventor Networks as Studied by Patent Co-inventorships

Ejermo, Olof; Karlsson, Charlie 
WP 2005/12

Knowledge Bases and Spatial Patterns of Collaboration: Comparing the Pharma and Agro-Food Bioregions Scania and Saskatoon

Coenen, Lars; Moodysson, Jerker; Ryan, Camille; Asheim, Bjørn; Phillips, Peter

WP 2005/13

Regional Innovation System Policy: a Knowledge-based Approach

Asheim, Bjørn; Coenen, Lars; Moodysson, Jerker; Vang, Jan

WP 2005/14

Face-to-Face, Buzz and Knowledge Bases: Socio-spatial implications for learning and innovation policy

Asheim, Bjørn; Coenen, Lars, Vang, Jan

WP 2005/15

The Creative Class and Regional Growth: Towards a Knowledge Based Approach

Kalsø Hansen, Høgni; Vang, Jan; Bjørn T. Asheim

WP 2005/16

Emergence and Growth of Mjärdevi Science Park in Linköping, Sweden

Hommen, Leif; Doloreux, David; Larsson, Emma

WP 2005/17

Trademark Statistics as Innovation Indicators? - A Micro Study

Malmberg, Claes 